\title{
Interpretation of Aeromagnetic Data to Investigate Crustal Structures of the Contact Congo Craton - Pan-African Belt at the Eastern Cameroon
}

\author{
Olivier Ulrich Igor Owono Amougou ${ }^{1}$, Théophile Ndougsa Mbarga ${ }^{1,2}$, Arsène Meying ${ }^{3}$, Jean Marcel Abate Essi ${ }^{1,4}$, Jean \\ Aimé Mono ${ }^{5}$, Didier Pepogo Manvele ${ }^{1} \&$ Christian Gislain Leonel $\mathrm{Ngah}^{1}$ \\ ${ }^{1}$ Postgraduate School of Sciences, Technologies \& Geosciences, University of Yaoundé I, PO Box 8251 Yaoundé, \\ Cameroon \\ ${ }^{2}$ Department of Physics, Advanced Teacher's Training College, University of Yaoundé I, P.O. Box 47 Yaoundé, \\ Cameroon \\ ${ }^{3}$ School of Geology and Mining Engineering, University of Ngaoundéré, Ngaoundéré, Cameroon \\ ${ }^{4}$ Ore Processing Laboratory, Institute for Geological and Mining Research, PO Box 4110, Nlongkak, Yaoundé-Cameroon \\ ${ }^{5}$ Department of Physics, Higher Technical Teacher's Training College of Douala, University of Douala, Douala, \\ Cameroon
}

Correspondence: Meying Arsène, School of Geology and Mining Engineering, University of Ngaoundéré, Cameroon.

Received: January 17, 2020

doi:10.5539/esr.v9n2p48
Accepted: February 25, $2020 \quad$ Online Published: June 8, 2020

URL: https://doi.org/10.5539/esr.v9n2p48

\begin{abstract}
The collision between the Congo Craton and the Pan African fold belt of Central Africa had great impacts on the geological and tectonic points of view, notably the installation of several tectonic accidents such as faults, fractures, dikes, folds, domes. This aeromagnetic study is based on Paterson's aeromagnetic data interpretations through the use of multiple operators. These data were processed by Oasis Montaj software. The total magnetic intensity map reduced to the equator (RTE-TMI) shows important anomalies features the major important regional anomalies. Maps of the vertical gradient, analytical signal and tilt angle maps have meanwhile highlighted several short wavelength anomalies assimilated to folding, dykes, fractures or faults. The map of maxima upward to $2 \mathrm{~km}$ allowed to establish the structural map of the study area. It turns out that the different types of geological accidents follow ENE-WSW, ESE-WNW, NE-SW, NW-SE and even E-W and N-S directions. All these directions are very similar to the geological history of the area. Anything that seems to confirm that the study area was the scene of intense tectonic movements resulting from the collision between the Congo Craton and the Central Africa Fold Belt.
\end{abstract}

Keywords: aeromagnetic data, fold, faults, lineaments, tectonic movement, Eastern Cameroon

\section{Introduction}

The analysis of lineaments represents an important step in geological survey. Several works interpret geophysical lineaments as faults or geological contacts (Atawa et al., 2018) or targets for mineralization emplacement (Abate Essi et al., 2017). The study area is characterized by tectonic features such as folds, faults and important undulations illustrated by previous geological works (Gazel \& Gerard, 1954; Toteu et al., 2004; Ngako et al., 2008). It is located in the contact zone between the two main geological domains of Cameroon namely Archean Congo Craton (CC) and Neoproterozoic Central African Fold Belt (CAFB) (Toteu et al., 2004).

The structural features observed in the study area, such as folds and faults, highlight the important tectonic activities occurred over the CAFB. Heavy magnetic and granite formations are represented by large circular geophysical anomalies (Owono-Amougou et al., 2019). All these identified structural elements are in accordance with the results obtained from previous geological and geophysical surveys (Meying et al., 2009; Feumoe et al., 2012) carried out in the study area and neighboring zones. Although belonging to the Pan-African belt, the study area presents structural features trending NW-SE that are described as the fingerprint of the CC (Owono-Amougou et al., 2019).

Aeromagnetic data are interpreted in order to have a better understanding of the tectonic environment of the study area which is located in the eastern part of Cameroon that comprises $04^{\circ} 30^{\prime}$ and $05^{\circ} 00^{\prime}$ latitudes and $13^{\circ} 00^{\prime}$ and $14^{\circ} 00^{\prime}$ longitudes. Magnetic survey is used to delineate magnetic lineaments, analyze its relationship to the tectonic fabric and to estimate the depth of perturbing body source. Aeromagnetic method is applied through various data analyses including 
horizontal gradient method (HGM), Euler deconvolution and upward continuation and inverse modeling. This multiscale investigation approach is fast, economical, without environmental impact and marked by a non-invasive implementation (Ndougsa Mbarga et al., 2012; Feumoe et al., 2012).

The objective of this study is the reinterpretation of aeromagnetic data collected in the South-eastern Cameroon region with a special focus on structural investigation of faults, folds using the multiscale approach of data processing techniques. This work performs a correlation between linear and circular structures with regional geology. The filtering of this potential field data will contribute to the understanding of crustal structure at the contact between CC and CAFB.

The achievement of this objective implies the filtering analysis of the total magnetic intensity (TMI) map. The first product of aeromagnetic survey will permit to observe wide spread anomalies. The application of derivative filters will underline geophysical lineaments, contact areas and then map the interpreted lineaments. In addition, the map of Euler's deconvolution solutions will permit to determine the characteristics of the structural features (Blakely, 1996; Reid, 1990).

\section{Geological and Tectonic Setting}

The CAFB is described as the results from the collision of stable zones namely West African and Sao-Francisco-Congo cratons, and Eastern Saharan Block (Ngako et al., 2011). It is considered as a rejuvenated and mobile zone (Rocci, 1965, Eno-Belinga, 1984), carrying several geological features inherited during historical events (Eno-Belinga, 1984). These geological marks make the CAFB architecture complex and interesting. The study area is located at the boundary between the Proterozoic CAFB and the Archean CC.

The CC crops out in Cameroon in its northwestern border, known as Ntem Complex. According to crustal evolution, the Ntem Complex is grouped into three stages namely (i) the formation of greenstone belt made of ortho-amphibolites and metasediments dated $3.1 \mathrm{Ga}$, (ii) the emplacement of tonalite-trondhjemite-granodiorite(TTG) suite about $2.9 \mathrm{Ga}$ and (iii) the formation of K-rich granitoids from TTG and greenstones belts melting between 2.7 and $2.5 \mathrm{Ga}$ (Van Schmus et al., 2008).

Based on its petrographic, isotopic and structural features, the CAFB is divided into three main domains in Cameroon namely North Western, Adamawa-Yadé and Yaoundé domains (Toteu et al., 2001). The study area overlaps the Adamawa-Yadé and Yaoundé domains separated by Sanaga fault (Figure 1). This dextral shear zone is a major crustal fault with a $\mathrm{N} 70^{\circ} \mathrm{E}$ general direction that was brought out by remote sensing (Dumont, 1986).

The Yaoundé domain represents more than $80 \%$ of the study area. This Neoproterozoic domain is a nappe that thrusts southward over the Congo craton. It consists dominantly of low grade gneiss to garnet bearing migmatites, low grade orthogneiss to granulite facies, and less late to post-tectonic granitoids (Toteu et al., 2004). Structurally, a polycyclic event is described in this part of the CAFB, marked by three main phases of ductile deformation. The first (D1) and the third (D3) phases correspond to alternating phase east-west to NW-SE contraction, while the second phase (D2) is translated by north-south to NE-SW extension. A fourth phase (D4) can be added to the precedent ones. This phase is coeval to D3 and defines a bulk vertical constriction (Mvondo et al. 2007b).

The Adamawa-Yadé domain is located at the north of SF. This domain is described as underlain by an Archean to Palaeoproterozoic basement. The study area includes a very little part of this domain. It comprises orthogneiss and metasediments, as well as granulitic gneiss reworked during Pan-African orogeny. Moreover, syn to late-tectonic granitoids crop out therein, with a transitional composition and crustal derived origin. (Toteu et al., 2004; Van Schmus et al., 2008). In this domain, two main deformation phases are identified. While the first phase is represented by a flat-lying foliation associated with isoclinal folds and a $\mathrm{N} 110^{\circ}-\mathrm{N} 140^{\circ}$ stretching lineation, the second phase is marked by the development of tight and upright folds with vertical axial plane foliations. The mineral lineation's and folds axes are parallel to a NNE-SSW to NE-SW direction with a variable plunge $0^{\circ}-50^{\circ}$ Sor $0^{\circ}-50^{\circ} \mathrm{N}$. 


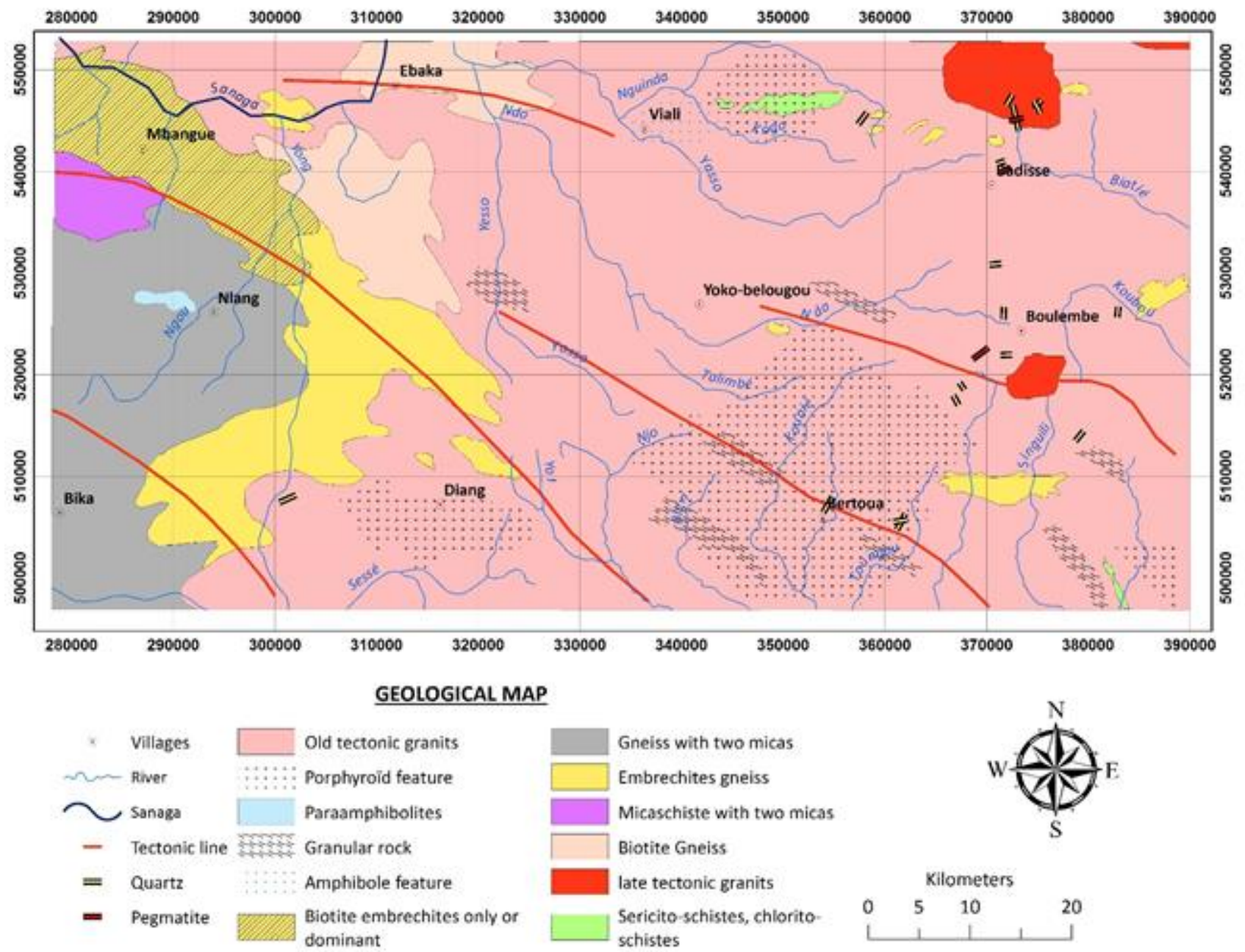

Figure 1. The geological map of the area of study (modified from Gazel \& Gerard 1954; Gazel 1955)

\section{Materials and Methods}

\subsection{Materials}

The dataset used in the present study is collected from the aeromagnetic survey in Cameroon (Paterson et al., 1976). This aeromagnetic survey was carried out between 1970 and 1976 by the Canadian company Survair Limited (Ottawa). The airborne survey was executed with the following parameters: flying height was $235 \mathrm{~m}$, flight lines followed a N-S direction with $750 \mathrm{~m}$ interlines spacing and the recording sensitivity of the magnetometer used was about $0.5 \mathrm{nT}$ precision. After applying measurement corrections for diurnal variations of the magnetic field, Paterson et al. (1976) presented results in maps with located station values. These maps were used to extract data value at each station under georeferenced system. The preliminary results express the total magnetic anomalies represented in Figure 2. The final report of Paterson et al. (1976) was accompanied by magnetic maps. Aeromagnetic data interpreted in this paper were extracted from one of these maps covering the study area. The total magnetic field data were continued upwards to a height of 500 meters.

The total magnetic intensity (TMI) map gives the vector sum of all the components of the magnetic field. TMI map reveals the magnetic characteristics of the various lithological units in the study area. The nature of magnetic anomaly is a function of strike of the body. The total magnetic intensity map shows deep structures, but has the disadvantage of having a noisy background generated by the long wavelengths. The map below (Figure 2) shows magnetic anomalies ranging from -130.85 to $62.61 \mathrm{nT}$ characterized by high and low frequencies. The study area has a magnetic relief disturbed by several anomalies. The map has two large parts along the diagonal (NW-SE direction). The upper part of the map is characterized by strong values of intensity of the magnetic field; on the opposite side, the lower part is characterized by low values of the magnetic field. 


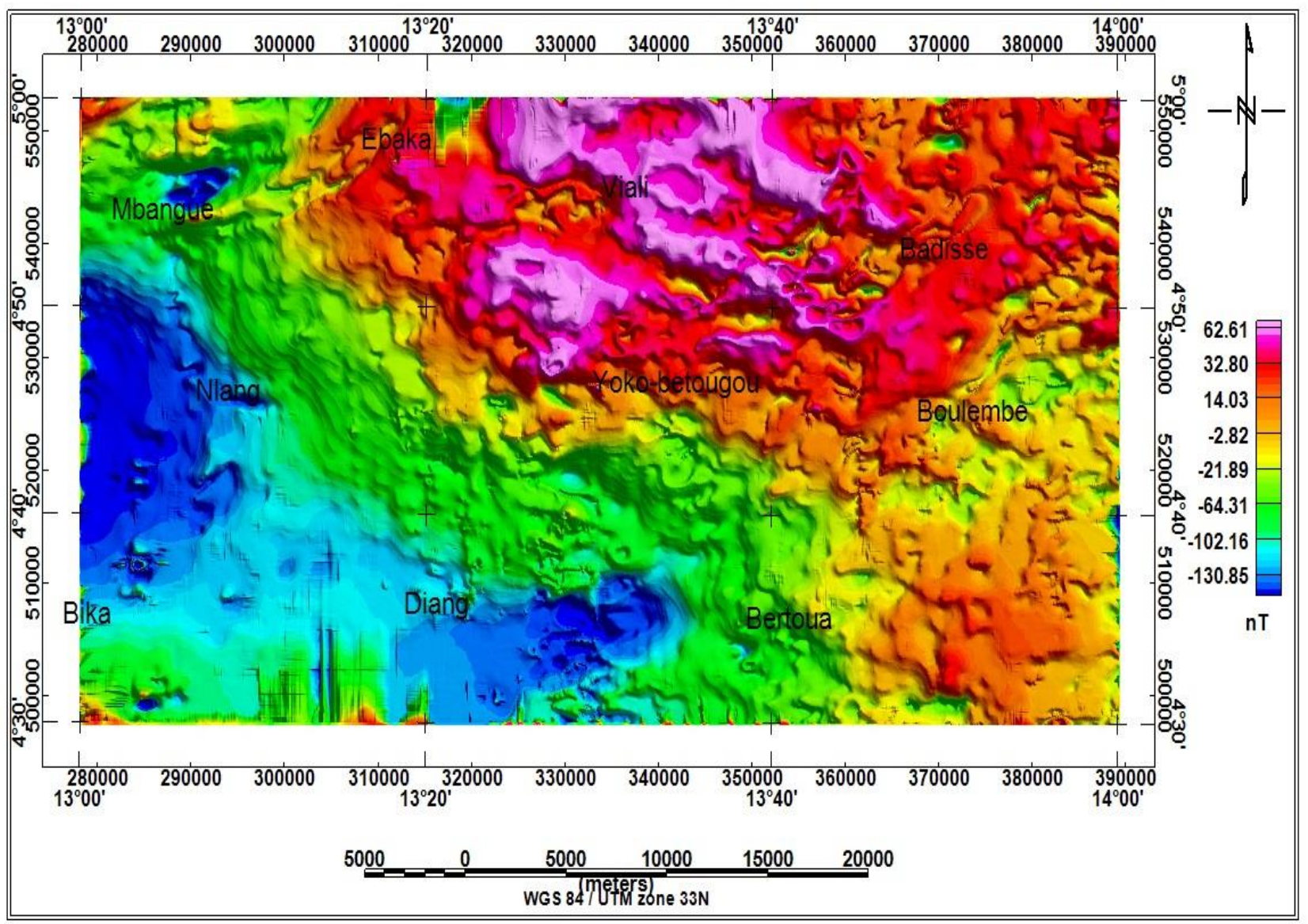

Figure 2. Total magnetic intensity anomaly map

These two parts are diagonally separated by a large NW-SE to ENE-WSW corridor, which consists in the average values of the magnetic field. This corridor seems to correspond to the tectonic line highlighted in the geological map.

\subsection{Methods}

In order to investigate the subsurface structure of the study area, a set of techniques is used namely vertical gradient, analytic signal, tilt angle transformation, upward continuation and Euler's deconvolution. The reduction to the equator is the preliminary treatment of the magnetic data. It consists in transforming magnetic anomalies into symmetrical patterns which would have been observed with horizontal magnetization.

\subsubsection{Reduction to Equator (RTE)}

This operation transforms the observed TMI into the anomaly that would have been measured if the magnetization and ambient field were both horizontal. It is therefore possible to have magnetic anomalies over their causative source facilitating the interpretation of geological features (Noutchogwe et al., 2010). Sedimentary rocks are not very magnetic and usually give low magnetic response (Clark, 1997, Gibson \& Milligan 1998, Mork et al., 2002). Therefore, the main sources of magnetic anomalies are assumed to depend on the magnetic properties of the subsoil (Feumoe et al., 2012). In this study, the reduction to the equator was performedon the date of 01/01/1970 where the values of the magnetic inclination $(\mathrm{Im})$ and declination $(\mathrm{Dm})$ are $\mathrm{Im}=-13.98^{\circ}$ and $\mathrm{Dm}=-5.33^{\circ}$ respectively.

\subsubsection{The Vertical Gradient}

The vertical derivative is used to amplify short wave-length anomalies and to focalize on the subsurface structures effects while attenuating the influence of high wavelength anomalies. The vertical gradient map has a capital importance in the structural interpretation of the area of study Feumoe et al. (2012). The algorithm is given by Gunn (1975):

$$
M(u, v)=M(u, v)\left(\left(u^{2}+v^{2}\right)^{\frac{1}{2}} / n\right)^{n}
$$

Where $\mathrm{M}$ represents magnetic fieldand $\mathrm{n}$ is the order of differentiation. 


\subsubsection{The Analytic Signal}

The method of analytic signal is used to locatemagnetic sources as developed by Nabighian (1974, 1984). The particularity of analytic signal is the independence of the magnetization direction from the source. Taking into account that the direction and intensity magnetic field vary according to time and place of observation, the analytic signal amplitude is simply linked to the value of magnetization (Rasolomanana et al., 2010). Roest et al. (1992). It shows that the amplitude of analytic signal is square root of the sum of the total magnetic field in relation to directions $x, y$ and $z$. Its expression is given by:

$$
|A(x, y)|=\sqrt{\left(\frac{\partial M}{\partial x}\right)^{2}+\left(\frac{\partial M}{\partial y}\right)^{2}+\left(\frac{\partial M}{\partial z}\right)^{2}}
$$

where $\mathrm{M}$ is the total magnetic field.

\subsubsection{The Tilt Angle Derivative}

The tilt angle transformation is the ratio of the vertical derivative to the total horizontal derivative of the magnetic field (Miller \& Singh 1994, Verduzco et al., 2004, Salem et al., 2008). The equation of this transformation is:

$$
\theta=\tan ^{-1} \frac{\frac{\partial M}{\partial z}}{\sqrt{\left(\frac{\partial M}{\partial x}\right)^{2}+\left(\frac{\partial M}{\partial y}\right)^{2}}}
$$

where $\mathrm{M}$ represents the magnetic field. The values of the angle tilt are between $\frac{-\pi}{2}$ and $\frac{\pi}{2}$.

This method delimits the amplitude variations of the angle in a certain range. The advantage of the transformation is that it calculates an angle and all the shapes of a given magnetic body will be represented in a similar way whatever the amplitudes of anomalies (Bouiflane, 2008). The amplitude of the tilt angle is positive for magnetic sources, almost zero at the edge of these sources and, is negative outside these magnetic sources (Muzaffer \& Unal, 2013); For a vertical contact, the null value corresponds to the limit of the magnetic structure (Amar et al., 2012).

\subsubsection{Upward Continuation}

This operator consists inassimilating, artificially, the observation plan and computing the magnetic field we could have observed in this new point. From the data collected, two types of extensions are distinguished (Bouiflane, 2008), namely the upward continuation which consists in attenuating the amplitude, and the smoothing which is a transformation that takes the anomaly from the altitude $z=0$ to the altitude $\mathrm{z}>0$. This operator corresponds to a low frequency filter that permits to attenuate high wavelength anomalies.

\subsubsection{Euler's Deconvolution}

This technique enables to locate sources responsible of anomalies. This method was described by Reid et al. (1990) and Thompson (1982). By considering a source $S$, situated at a point $P_{o}\left(\boldsymbol{x}_{\mathbf{0}}, \boldsymbol{y}_{\mathbf{0}}, \mathbf{z}_{\mathbf{0}}\right)$, the intensity of the total magnetic field at the observation point $\mathrm{P}$ is:

$$
f\left[\left(x-x_{0}\right),\left(y-y_{0}\right),\left(z-z_{0}\right)\right]=M(x, y, z)
$$

The homogeneity equation has been established by Thompson (1982), and written as follow:

$$
\frac{\left(x-x_{0}\right) \partial M}{\partial x}+\frac{\left(y-y_{0}\right) \partial M}{\partial y}+\frac{\left(z-z_{0}\right) \partial M}{\partial z}=N(B-M)
$$

where $(x, y, z)$ represent the coordinates of the observation point, $\left(x_{0}, y_{0}, z_{0}\right)$ the coordinates of the magnetic source, $M$ the total magnetic field at the observation point, $B$ the regional value of total magnetic field and $N$, is called structural index and it characterizes the type of source and the variation rate of the field in relation to the distance. The Euler's deconvolution principle relies on the solution of the previous equation (5) with four unknown quantities $x, y, z$ and B (Amar et al., 2012). To solve a system of equations with four unknown quantities, we need four measure points, then we proceed with the least squares method (Feumoe et al., 2012).

The structural index is $N=-n$, where $n$ is the degree of homogeneity and depends on the geometry of the source. Thus, for a homogenous source the structural index $N=3$ corresponds to a linear source (dipole line or poles, homogenous cylinder, rod, etc.), $N=2$ for intrusive bodies (dyke, thin layer, etc.), $N=1$, for contact; $N=0$ for block and pyramid vertex. 


\section{Results}

\subsection{Total Magnetic Intensity Anomaly Reduces to the Equator Map}

In this study, the reduction to the equator was performed on the date of 01/01/1970 involving the values of the magnetic $(\mathrm{Im})$ inclination and declination $(\mathrm{Dm})$ are $\mathrm{Im}=-13.98^{\circ}$ and $\mathrm{Dm}=-5.33^{\circ}$ respectively. The total magnetic intensity reduced to the equator (RTE-TMI) is presented on Figure. 3. This map is useful to interpret deep structures. The main sources responsible of the observed magnetic anomalies depend on the magnetic properties of the basement rock (Feumoe et al., 2012). The anomaly passes from any form to a characteristic symmetric form, with a central latitudinal lobe surrounded in North and South by two lobes of opposed sign to the first.

On Figure 3, a relatively good correlation between the observed anomalies and the geology of the study area is observed. The granites geological mapped by (Gazel, 1955; Gazel \& Gazel, 1954) in the north might be characterized here by the great and medium amplitudes reaching $43.06 \mathrm{nT}$. The micashists could be characterized by low amplitudes reaching -122.77 nT. Granites and micashists up-cited might be separated by gneiss rocks, characterized by magnetic anomalies with amplitudes ranged between $-78.38 \mathrm{nT}$ and $-30.61 \mathrm{nT}$. The anomaly map of the total magnetic field reduced to the equator (Figure 3) shows almost symmetrical anomaly. The negative anomalies have moved to the southeast that could suggest that, these anomalies were probably associated to the body having a well-induced behavior.

The area of study shows a magnetic relief perturbed by many anomalies. It is divided into three main magnetic domains. The North and East parts characterized by elevated values of the magnetic field; the west and South parts characterized by very weak values of the magnetic field; also, there is a domain constituted of the intermediate values which takes all of the NW-SE diagonal. This intermediate domain forms a corridor which seems to properly correspond to the tectonic line emphasized on the geologic map. We can equally note the presence at the north-west, another structural direction (ENE-WSW), this could well be linked to the river Sanaga fault.

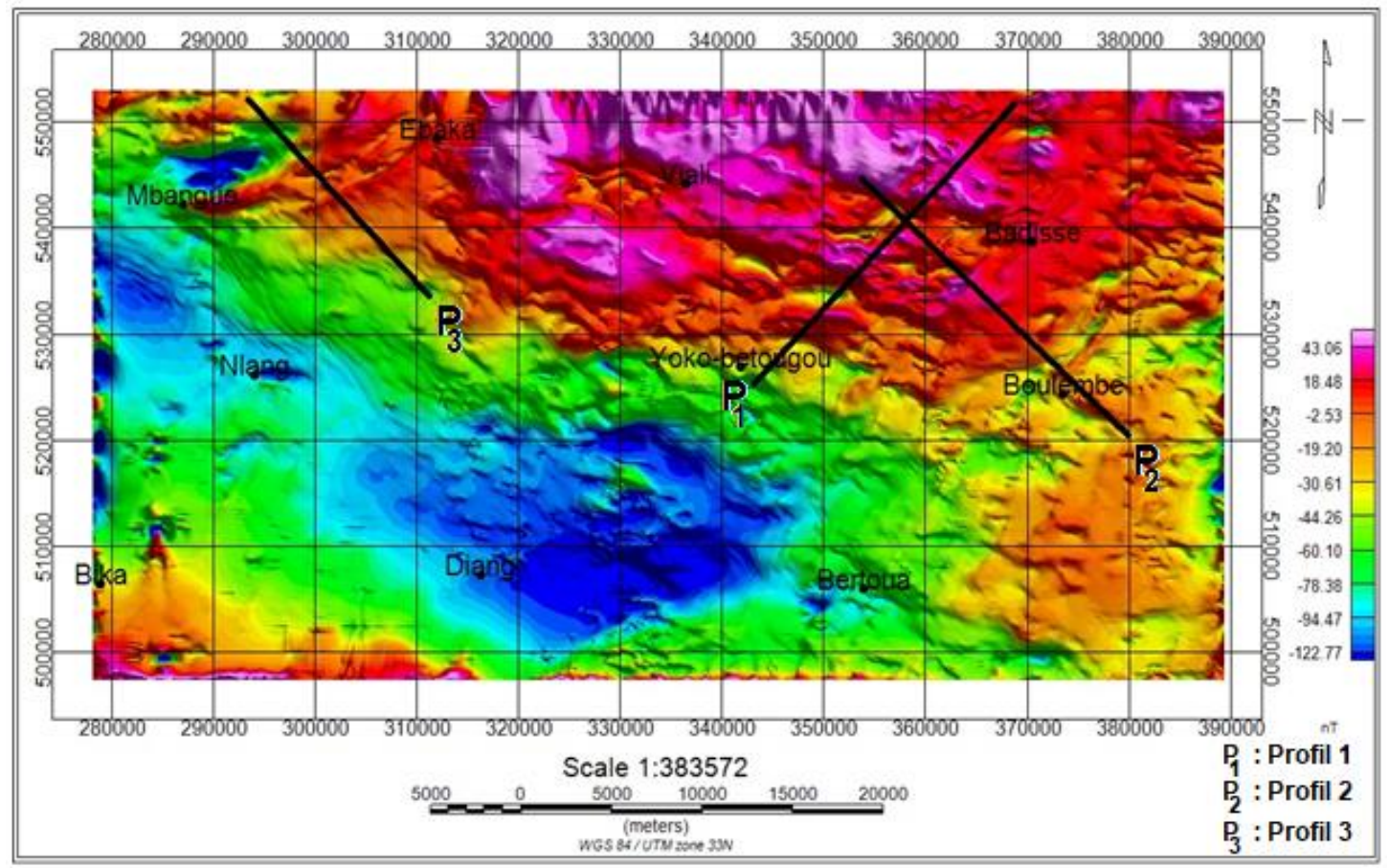

Figure 3. Total magnetic intensity map reduced to the equator

\subsection{Residual Map}

The residual anomalies map (Figure 4) is deduced from the difference between the basic TMI and the upward continued TMI at $2 \mathrm{~km}$ distance. The application of the upward continuation technique smooths the signal of superficial geological structures and amplify the effect of deeper formations. Thus, the residual anomalies map brings out essentially the effect of shallow magnetic masses. In the study area, the maximum value of residual anomalies 17,141 nT, while the highest anomaly of TMI-RTE is $61 \mathrm{nT}$. This difference highlights that the magnetic signal of the superficial structures is masked by the one of the deep structures. Maxima of anomalies are elongated and mainly follow ENE-WSW, NW-SE, ESE-WNW, NE-SW and E-W directions. The areas of high magnetic susceptibilities observed in the RTE-TMI map in the north, west, center and Bertoua areas are also well observed here. 


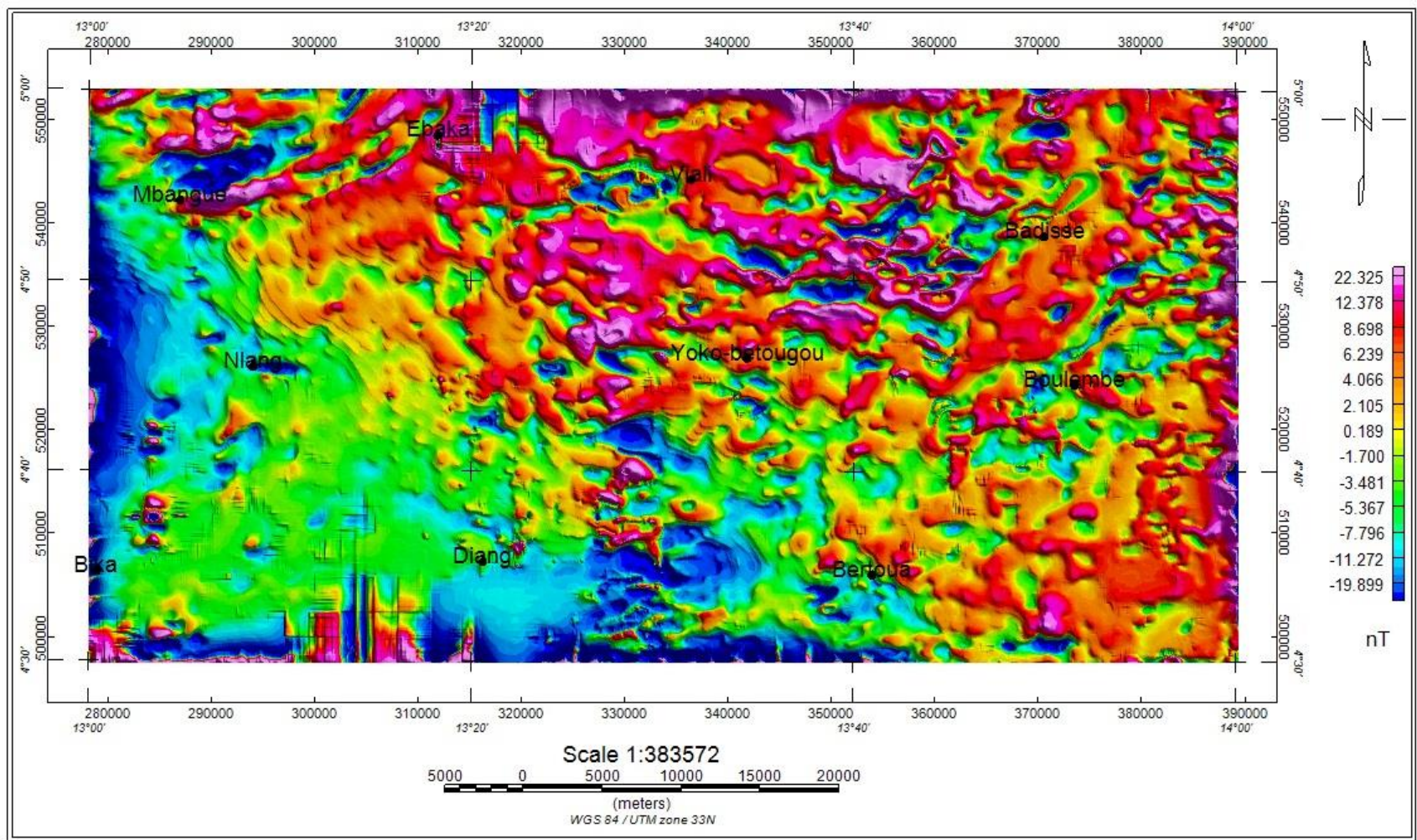

Figure 4. Total magnetic intensity reduced to the equator residual map

\subsection{Analysis of the Map of the Vertical Derivate}

The vertical gradient map of the study area (Figure 5) exposes superficial structures and the high wavelength anomalies observed on the total magnetic field map (Figure 2) have been attenuated. The high values of circular anomalies previously observed in the zones of Nika, Mbangue, Ebaka and in the north of Bertoua have not been attenuated. This confirms that they are linked to deep structures. Several fine and rectilinear anomalies are identified and they follow various directions namely NE-SW, NW-SE, ENE-WSW and ESE-WNW at the East and North-West sides of the map. The different lineaments observed here are short wave length range and seem to fall in line; this justifies the existence of a network of abrupt faults. The most important directions fall in the ENE-WSW, NE-SW, ESE-WNW, NW-SE. We also have E-W N-S the anomalies of the NW-SE correspond to tectonic lines evidenced in previous studies. 


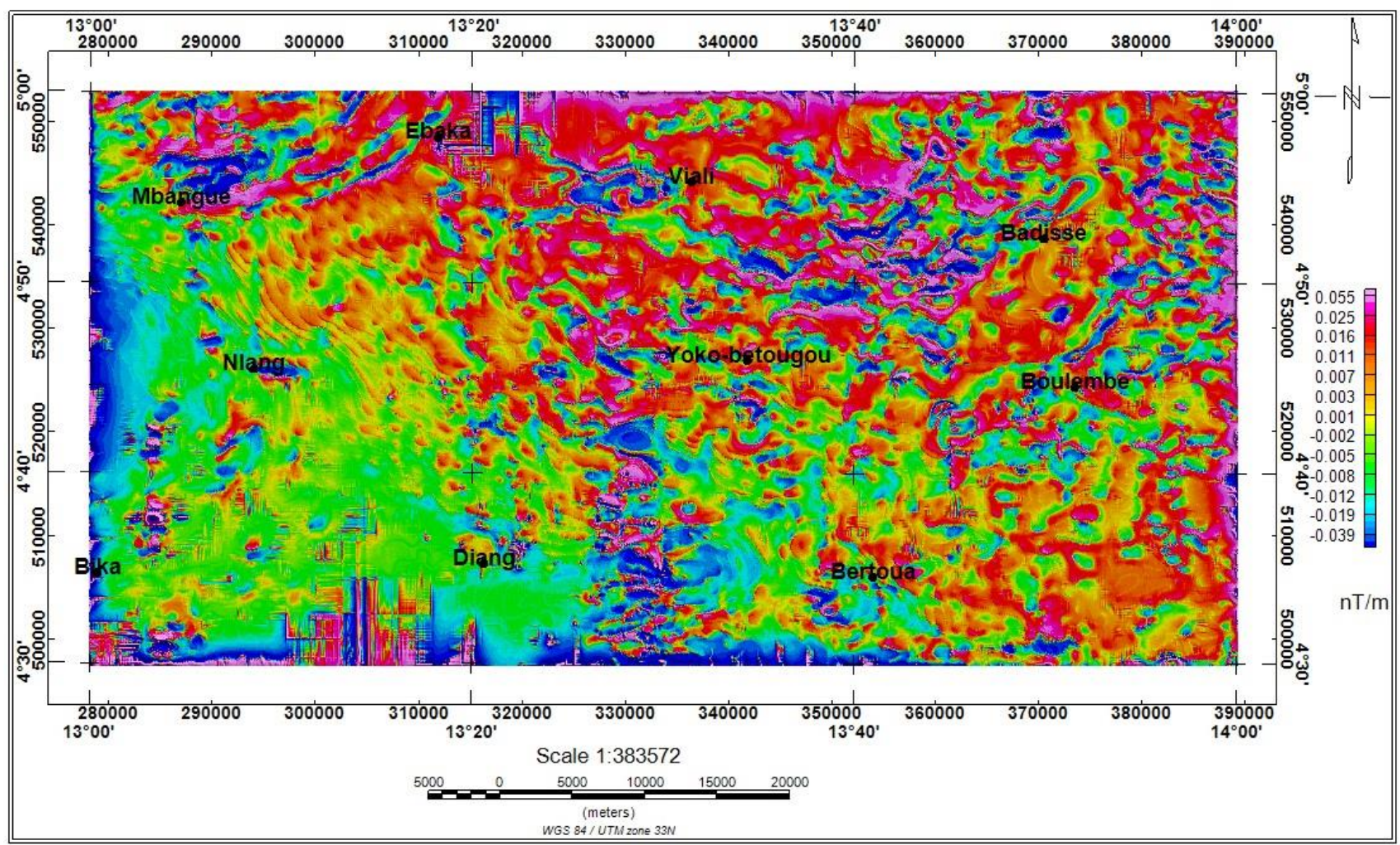

Figure 5. The vertical gradient map

\subsection{Analysis of the Analytic Signal Map}

The analytic signal brings out the contact of the geological bodies of strong magnetization. In addition, this treatment of magnetic signal is focused on high frequencies that correspond to short wavelengths. The analytic signal map (Figure 6) of the study area reveals the following observations:

In the Mbangue area, the presence of a circular magnetic anomaly that denotes the presence of a magnetic intrusion. In the area of Badisse and its surroundings there are also several clusters of magnetic structures. Similarly, residual magnetic anomalies are located at the north of Bertoua zone. Besides, at the west of the study area, strong gradients anomalies are distinguished. Some structures are linear and folded; thus exposing tectonic features such as fractures, faults, dykes or folds in the geological basement. These aforementioned directions NE-SW, NW-SE, ENE-WSW, ESW-WNW, E-W and $\mathrm{N}-\mathrm{S}$ can easily be identified. Structures with circular or subcircular shapes may denote the presence of post tectonic features like late tectonic granite at the north of Badisse locality. 


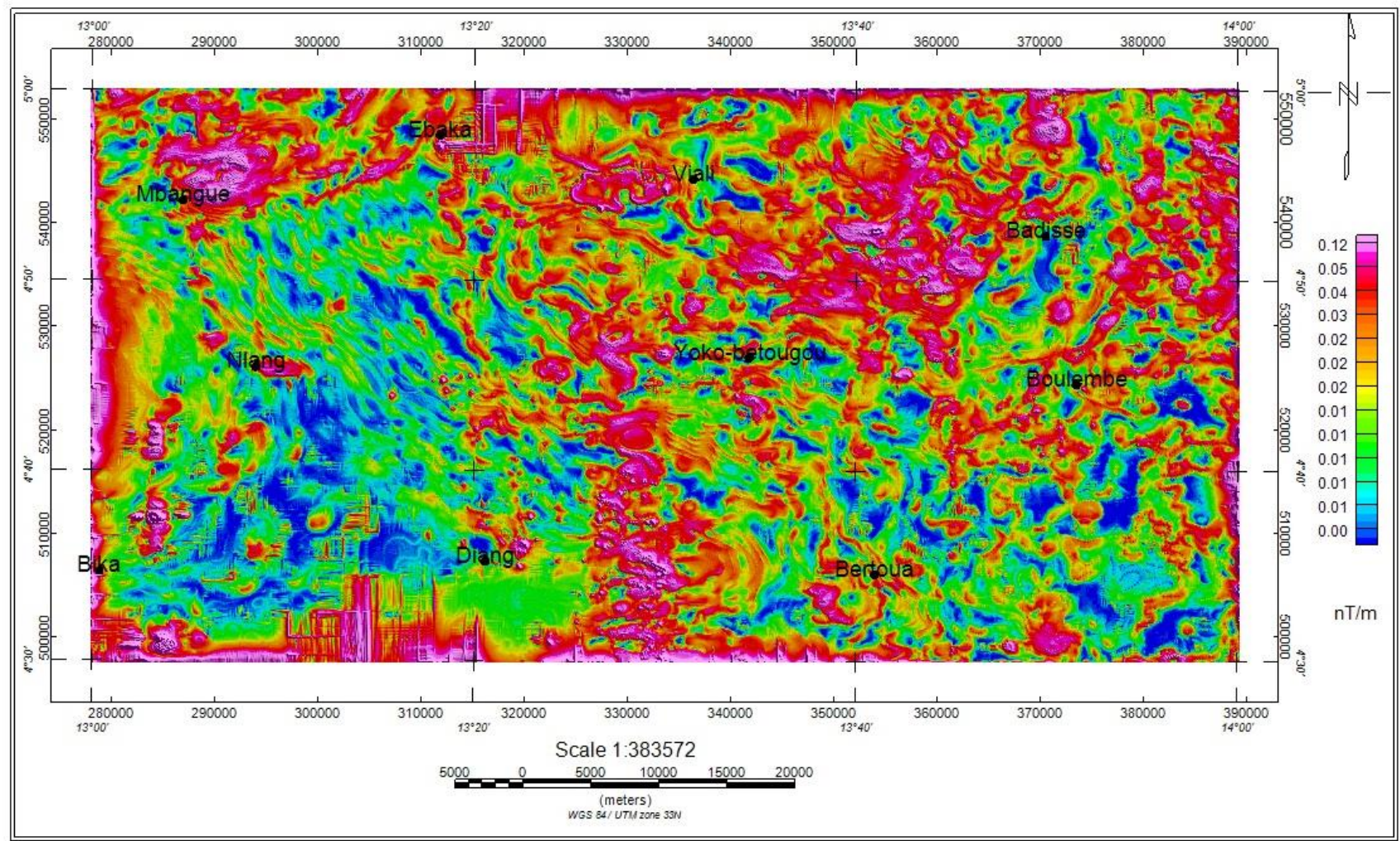

Figure 6. Analytic signal map

\subsection{Analysis of the Tilt Angle}

The tilt angle derivative of the study area is presented in Figure. 7. It highlights secant lineaments and dykes. Several lineaments trending NW-SE are in the western part of the map. In the North-West, the lineaments are oriented NE-SW. In the eastern, northern and central parts of the map, we observe lineaments trending NE-SW, NW-SE and E-W. The NE-SW lineament system observed in the western part of the study area divides the map into two domains. The first domain is strongly magnetic and is situated at the Northeast while the South-West domain is characterized by low values of the magnetic field. The anomalies present the wavy form which expresses the metamorphism or dynamo-metamorphism with intense folding. The map above also shows three different magnetic domains as observed on the map of the total magnetic field, particularly in the northeast a strongly magnetic domain, in the southwest a domain with low magnetic field values and an intermediate zone separating the magnetic fields.

On the NW-SE intermediate zone, there are several blade-shaped structures that follow this direction. These would correspond to a succession of NW-SE directional fractures. In the northeastern part, there are several shears, of which one of the most remarkable is observed to the north-west of the study area. We also note the presence of several blade-shaped structures, which correspond to the dikes. In this part of the map, we also observe pleated structures that follow the NW-SE, NE-SW or E-W directions. Several flaws are also highlighted here. Moreover, several dykes are observed throughout the entire southwestern part of the study area. 


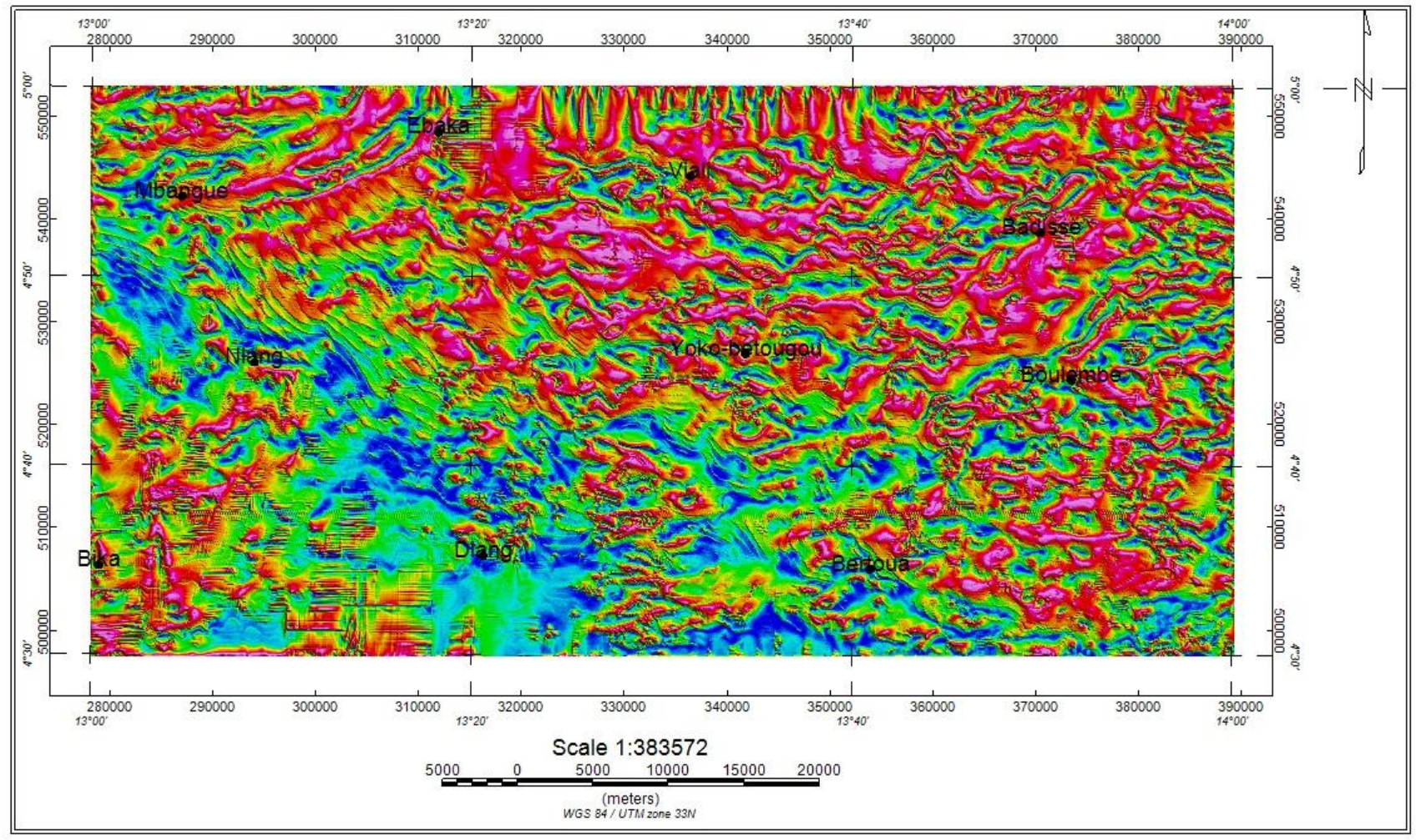

Figure 7. Tilt angle derivative map of the study area

\subsection{Superposition of Maxima of Vertical Gradient, Analytic Signal and Tilt Angle Upward Continued to $2 \mathrm{~km}$}

A summary of previous analyses is performed in Figure.8. The map presents precisely the superposition of maxima of vertical gradient, analytical signal, and tilt angle derivative upward continued at $2 \mathrm{~km}$ distances. It individualizes the magnetic peaks of filtered field interpreted as geological structures such as contacts, fractures, folds and even faults and is composed of key-elements for the structural of the study area. 


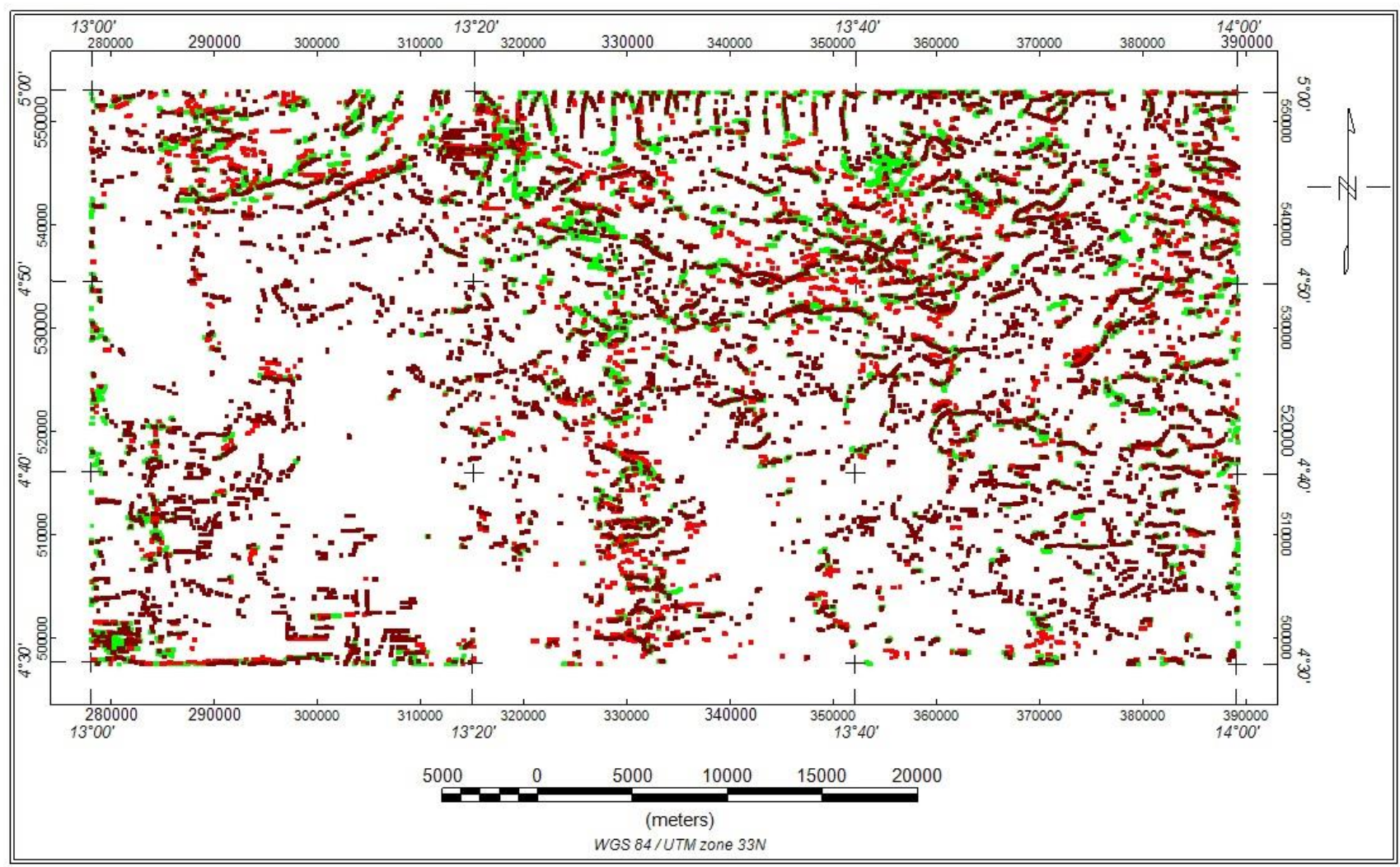

Figure 8. Superposition of maxima of vertical gradient, analytic signal and tilt angle derivative upward continued at 2

$\mathrm{km}$

\subsection{Structural Map of the Study Area}

The structural map (Figure. 9a) summarizes the main lineaments of the study area, deduced from the superimposition of the vertical gradient, analytical signal, and tilt angle derivative upward continued at $2 \mathrm{~km}$ maxima. The different lineaments observed here are linked to the geodynamic of the Braziliano-Africa mobile zone related to the impact of the collision between the West African and the Congo - Sao Franscico Cratons (Toteu et al., 2004; Abate Essi et al., 2017). The Central Northern part of the study area has more lineaments. This may be due to the multiple phases of deformations that have affected the Pan-African domain (Mvondo et al., 2007b). This Central Northern sector represents therefore the mobile CAFB while the Western Southern part would correspond to the table Craton of the Congo. These lineaments are characterized by NW-SE, NE-SW, ESE-WNW, ENE-WSW and E-W. These directions have been highlighted on a regional scale through multiple geological and geophysical works (Owono-Amougou et al., 2019). The NE-SW and ENE-WSW directions are of the most important structural features. They are inferred from a series of intense deformation accompanied by plutonic intrusions and a granitization. They tally with the orientation of the great major Pan-African tectonic structures in Cameroon like Sanaga fault, Central Cameroon Shear Zone, Tcholliré Banyo Shear zone. NW-SE and WNW-ESE directions have been acquired during the emplacement of the CAFB and the one of the Adamawa plateau structures. It also seems to be correlated with the direction of the subduction of the CAFB towards CC. The E-W direction brought out in the study area corresponds to the sub-horizontal direction of the extension undergone by the granitic magma during its location (Ndougsa Mbarga et al., 2012). 


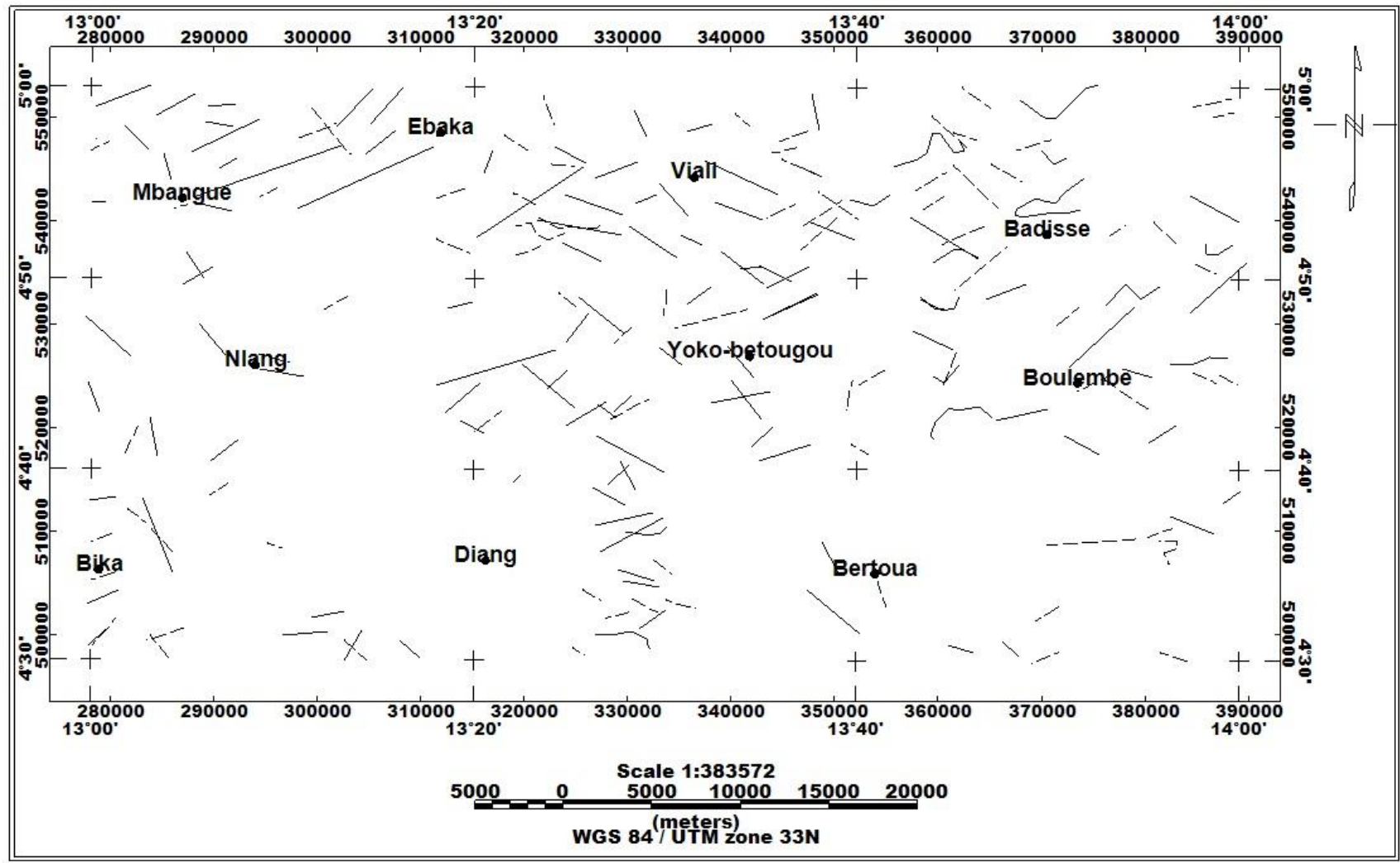

Figure 9a. Structural map of the study area

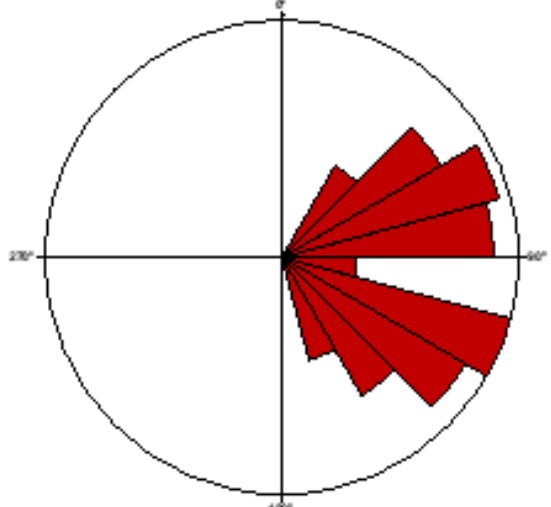

a)

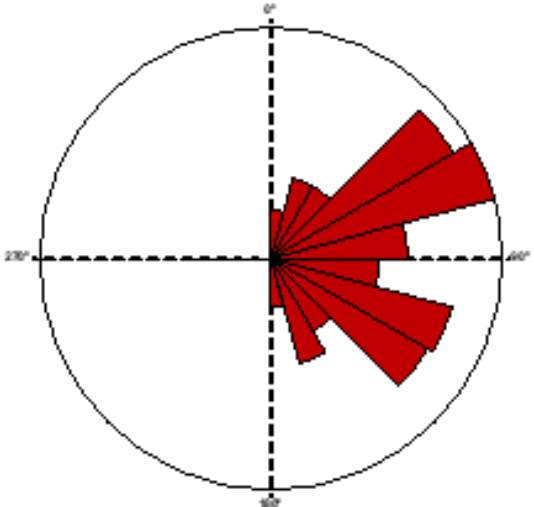

b)

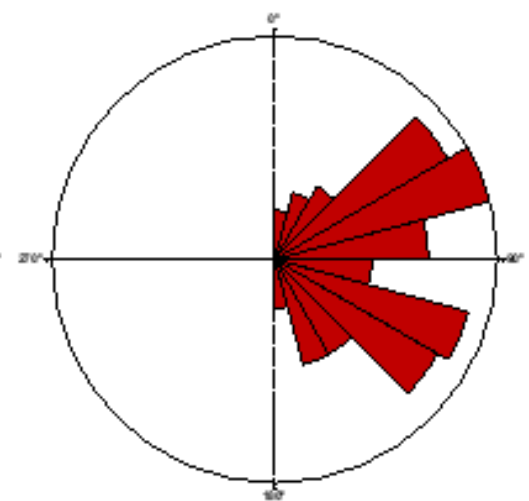

c)

Figure 9b. a) Rose diagram of the major lineaments; b) Rose diagram of the minor lineaments; c) Rose diagram of the general lineaments of the study area

\subsection{3/4-D Modeling}

This work implies magnetic modeling of field to illustrate the basement of the study area. Based on the algorithms described by Won \& Bevis (1987) and Rasmussen \& Pedersen (1979), the extension GM-SYS of Geosoft Oasis Montaj enables to build a proper geological basement from the optimal fit of the generated source curve model to the observed data curve. The calculated responses of the magnetic bodies change iteratively with the change of the model parameters, particularly the magnetic susceptibility and shapes of bodies. Three rectilinear profiles (P1, P2, P3) are selected on the RTE-TMI mapto predict the location and shape of the causative magnetic source. Figure 10, 11 and 12 reveal the forward modeling of the profile $\mathrm{P}_{1}, \mathrm{P}_{2}$, and $\mathrm{P}_{3}$ respectively. 


\section{Profil 1}

The magnetic profile P1 is oriented ENE-WSW and located near the Badisse locality. It is long about $37 \mathrm{~km}$ and centered on a high anomalies area. Based on magnetic signatures in relation to the local geology, five lithological layers can be highlighted including late and syn tectonic granites, embrechites gneiss, sericito-schists and sediments. The general basement of this profile is defined as granite; two intrusive bodies are distinguished and characterized by a different magnetic response. The first body is the least bulky with a subcircular shape and is located towards the end of the profile, while the second body is more magnetic, shallow and located around $10 \mathrm{~km}$ and $25 \mathrm{~km}$. The $2^{3 / 4} \mathrm{D}$ magnetic model of this profile shows an undulated curve consisting of positive or negative magnetic anomalies. We deduced the presence of non-magnetic rocks responsible of negatives values of the curve

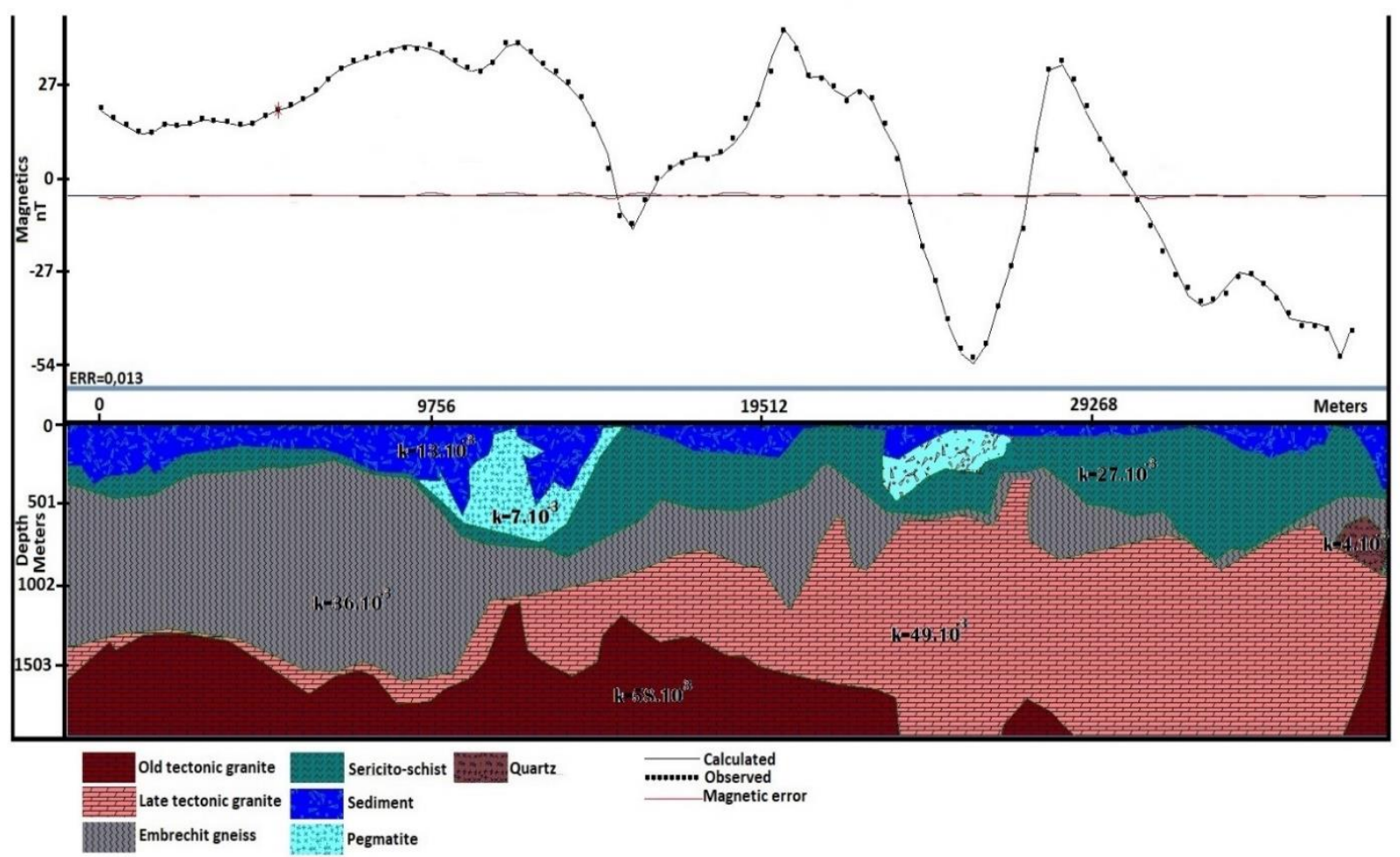

Figure 10. Model of profile 1

The above-mentioned magnetic bodies are found on tectonic accidents within Pan-African formations. This area is ancient and continental pro-parte, Paleoproterozoic aged taken over Pan African orogeny. These bodies would be the result of the multiple phases of deformations that affected the Pan-African notably by brittle tectonics accompanied by folding or shearing events (Mvondo et al., 2007b).

Profile 2

The magnetic profile P2 oriented ESE-WNW and located in the Badisse locality is long about $35 \mathrm{~km}$. Itsends are the coordinate points $(354691 \mathrm{~m} ; 544194 \mathrm{~m})$ and $(379862 \mathrm{~m} ; 520621 \mathrm{~m})$. It crosses dominantly four layers namely old tectonic granites, embrechite gneiss, sericito- and sediments with a granitic basement. Within these geological layers, three intrusive bodies are brought out with a different magnetic response. These intrusions shapes are subcircular. 


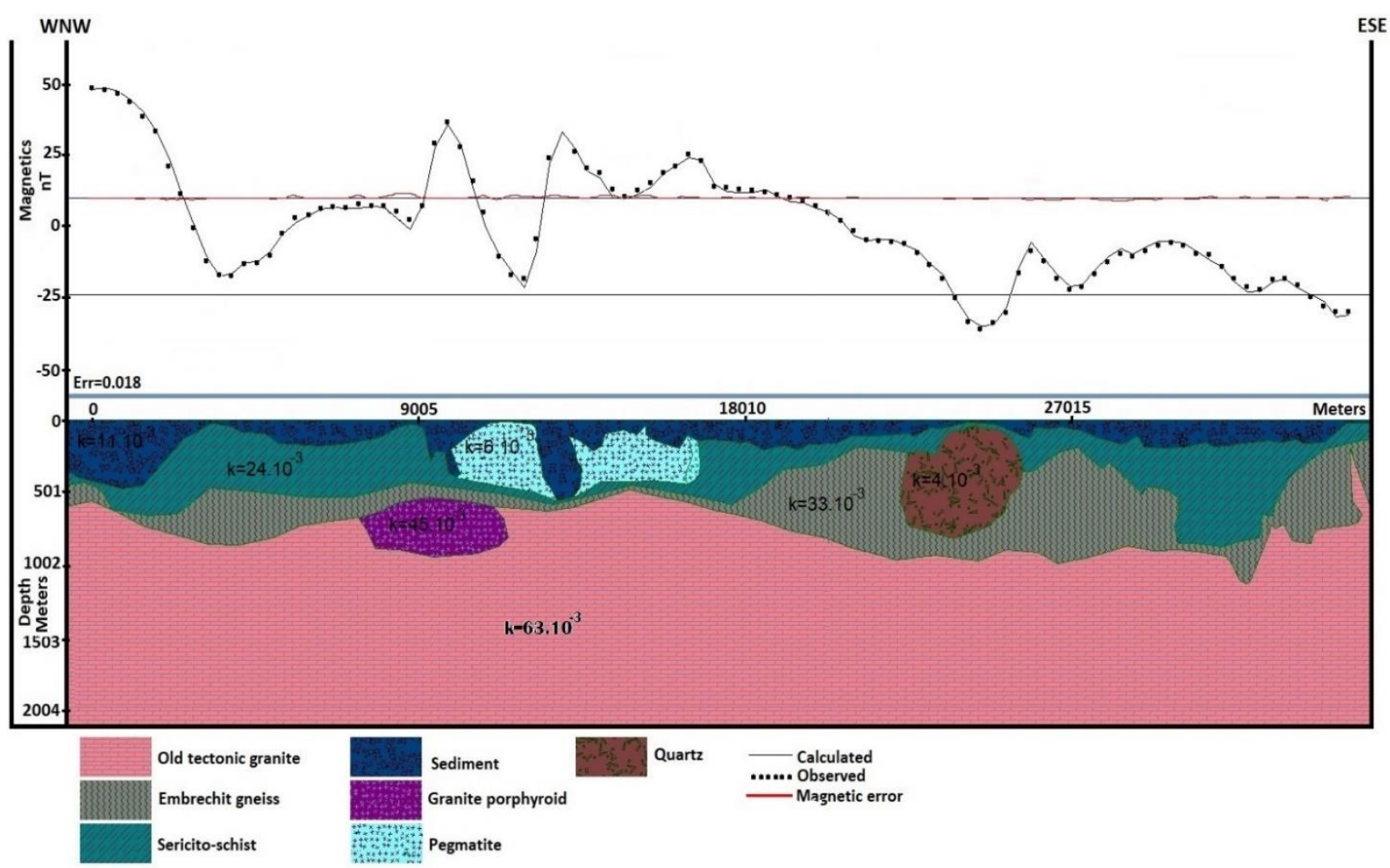

Figure 11. Model of Profile 2

The $2^{3 / 4} \mathrm{D}$ model of this profile shows that it is disturbed by a magnetic relief characterized by positive and negative anomalies. The magnetic bodies buried in the geological layers described in the profile 1 are found on the tectonic accidents in the Neoproterozoic Pan-African formations. This domain corresponds to distinct orogenic structures. They can be interpreted as the result of the principal phases of deformation that are affected by the Pan-African belt, notably by brittle and ductile (Mvondo et al. 2007b). This assumes the occurrence of a contact metamorphism in the study area.

Profile 3

The magnetic profile P3 trending ENE-WSW, is located near the Mbangue locality. It is characterized by a length about 25 $\mathrm{km}$. 


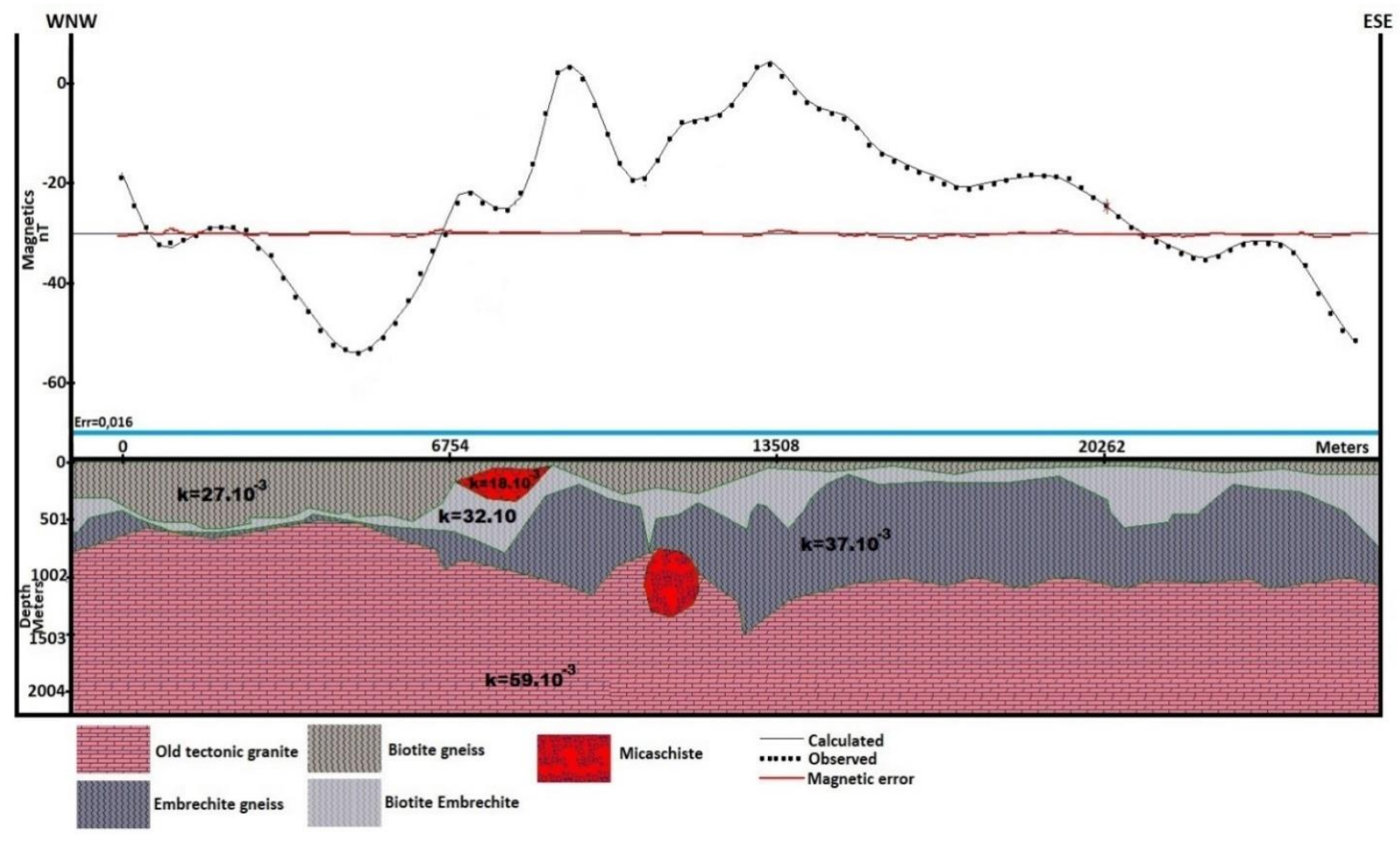

Figure 12. Model of profile 3

The magnetic profile P3 passes through weakly magnetic formations. The magnetic topography along the profile P3, in accordance with the known local geology, enables to define a granitic basement made of four geological layers chiefly, of biotite, embrechites, biotite gneiss, and embrechite gneiss. Besides, Figure 12 exposes the presence of two magnetic bodies characterized by spherical or ellipsoidal shapes and different magnetic susceptibilities. These bodies are buried within old tectonic granites and on the embrechite gneiss. The subduction of Pan African belt on CC played an important role to the emplacement of this syn-tectonic intrusions. The magnetic bodies are hosted on tectonic accidents precisely at about $400 \mathrm{~m}$ or even $1000 \mathrm{~m}$ depths.

\section{Discussion}

The RTE-TMI map (Figure 3) enables to split the study into three important anomaly sectors. The northern eastern part that is characterized by high amplitude magnetic anomalies; the southern western part where very low anomaly values of the magnetic intensity are observed, and finally, a corridor with negative anomaly values which separates the two sectors mentioned above. This distribution of magnetic anomalies correlates with previous geological observations (Gazel, 1955; Gazel \& Gerard, 1954). Granites and migmatites outcropped mostly in the northern eastern and southern eastern areas respectively, while a corridor consisting of gneiss rocks separates them. The wide corridor separating the two sub-areas relatively tally with the tectonic line highlighted by Gazel \& Gerard (1954). Owono-Amougou et al. (2019) locate bodies of responsible these anomalies within the crust and suggest that they are characterized by high magnetic properties.

Structurally, the vertical gradient anomaly map (Figure 5) highlights many undulated short wavelength anomalies in the study area. They could be correlated to brittle and ductile structural deformations such as folds and foliations that are witnessed. The tectonic intensity occurred over the study area. (Mvondo et al., 2007b) link the origin of these structural events to general ductile deformations of the basement related to Huronian orogeny. Generally, the structural deformations in the study area are mostly oriented WSW-ENE, ESE-WNW, SE-NW, SW-NE, E-W. From the regional scale, the folding system trending NE - SW and NW - SE, are in accordance with the directions of the deformation history of the Neoproterozoic Central African Belt in Southern Cameroon (Mvondo et al., 2007b). This disposition of aligned short wavelength anomaly shows the presence of other structural facts such as fault. According to the various observed structural features, the basement seems to have replayed tectonically creating different generations of deformation. These structural features have already been confirmed by previous geophysical surveys, carried out in gravity (Ndougsa Mbarga et al., 2003), magnetotellurics (Ndougsa Mbarga et al., 2011; Meying et al., 2009) and airborne magnetic (Feumoe et al., 2012).

The vertical gradient, tilt derivate, analytic signal map and the map of the superposition of the maxima of vertical 
gradient, analytical signal, and tilt angle upward continued to $2 \mathrm{~km}$ show four main families of lineaments directed respectively ENE -WSW, ESE-WNW, NW- SE and NE- SE. The NE-SW observed trend is the outcome of compression which has occurred along the NW - SE axis during the regional metamorphism. This structural direction is resulted from the collision of the CAFB and the CC as proposed by some authors (Toteu et al., 2004; Ngako et al., 2008). The ENE - WSW and NE - SW direction corresponds to the SCSZ (Toteu et al., 2004) and result to the compression which has occurred along the NW-SE axis during the regional metamorphism. The lineaments with a NW-SE and ESE -WNW trends seem to correlate with those resulted from the Panafrican orogeny and correspond to the limit between the CAFB and the CC as put in evidence by Basseka et al. (2011). The concerned trends are also corresponding to those identified on the Adamawa plateau in the work of Noutchogwe et al. (2006) as well as the survey carried out by Dumont et al. (1985) recognized as the Central Cameroon shear zones.

Various indices make it possible to confirm the hypotheses emitted by the different magnetic models $2.3 / 4 \mathrm{D}$, in particular the structural study made previously showed the presence of a certain number of geological accidents located on the flanks of the various anomalies. Due to the geologico-tectonic context of the study area, with the subduction of the Craton under the Pan-African, on the one hand and on the other hand the different deformations that affected the Pan-African domain, the entire base would have played several times giving rise to many fractures, breaks or faults more or less important. These different deformations are of Dahomeyan and Birminan origin (Gazel \& Gerard 1954).

Thus, these profiles allowed to observe intense folding and shearing in the substratum, which are characterized by crushing structures which have subduction imprint of the Pan-African domain in the CC. These analyzes correlated well with those conducted both in the geological works by (Toteu et al., 2004, Mvondo et al., 2007a \& b) and in the geophysical work by (Owono-Amougou et al., 2019; Zanga et al., 2013).

\section{Conclusion}

This study is based on the analysis and interpretation of aeromagnetic data to investigate crustal structures of contact between Congo Craton-Pan African Belt of the study area, using multiscale analysis. Superposition of maxima of vertical gradient map, tilt angle map and analytic signal map highlight lineaments, defined as fault, dykes, folds or geological contacts. Major magnetic lineaments trend in ENE-WSW, ESE-WNW, NW-SE, NE-SW directions with minor ones trending in E-W and N-S direction. These structural features highlight the important tectonic movements affecting the study area. Among faults and folds revealed from this study, some have been confirmed by previous studies (notably Owono-Amougou et al., 2019) while others are inferred from the current investigation. $2 .^{3 / 4} \mathrm{D}$ modeling has permitted to observe geological structures on the subsoil such as observed in the magnetics profiles. Thus, these profiles allowed to observe intense folding and shearing in the subsoil, accompanied by crushing of the characteristic structures with subduction imprint of the Panafrican domain in the Congo Craton. These analyzes correlated well with those conducted both in the geological works (Toteu et al., 2004, Mvondo et al., 2007 a \& b) and in the geophysical works conducted by Zanga et al. (2013) and Owono-Amougou et al. (2019).

\section{Acknowledgments}

This work was carried out at the University of Yaoundé I, Cameroon, as part of first author's Ph.D studies. The authors are grateful to the reviewers and the readership for their kind help in making the manuscript clearer, more correct and mature for publication.

\section{References}

Amar, M., Manar, A., \& Boualoul, M. (2012). Apport de la cartographie aéromagnétique à l'identification structural du système aquifère des sources de l'Oasis de Figure (Maroc). Bulletin de l'Institut Scientifique, Rabat, section Sciences de la Terre, 34, 29-40.

Basseka, C. A., Shandini, Y., \& Tadjou, J. M. (2011). Subsurface structural mapping using gravity data of the northern edge of the Congo Craton, South Cameroun. Geofizika, 28(2), 229-245.

Blakely, R. J. (1996). Potential theory in gravity and magnetic applications. Cambridge university press. https://doi.org/10.1017/CBO9780511549816

Bouiflane, M. (2008). Cartographies aéromagnétique et magnétique multi-échelles: étude structurale d'une région du Fossé rhénan (Doctoral dissertation, Strasbourg 1).

Clark, D. A. (1997). Magnetic petrophysics and magnetic petrology: aids to geological interpretation of magnetic surveys. AGSO Journal Australian Geology \& Geophysics, 17(2), 83-103.

Cornachia, M., \& Dars, R. (1983). Un trait structural majeur du continent africain: Les linéaments centrafricains du Cameroun au Golfe d'Aden. Bulletin de la Société Géologique de France, 25(1), 101-109. https://doi.org/10.2113/gssgfbull.S7-XXV.1.101 
Dumont, J. F. (1986). Identification par télédétection de l'accident de la Sanaga (Cameroun). Sa position dans les grands accidents d'Afrique Centrale et de la limite Nord du Craton du Congolais. Géodynamique, 1(1), 13-19.

Dumont, J. F., Toteu, S. F., \& Penaye, J. (1985). Ensembles structuraux et principales phases de déformations panafricaines dans la zone mobile du Nord Cameroun, région de Poli. Revue Science et Technique. Série Sciences de la Terre, 1(1/2), 9-23.

Eno Belinga, S. M. (1984). Géologie du Cameroun. Librairie Universitaire de Yaoundé, République Unie du Cameroun (307 p).

Essi, J. M. A., Marcel, J., Atangana, J. Q. Y., Ahmad, A. D., Dassou, E. F., Mbossi, E. F., ... \& Penaye, J. (2017). Interpretation of gravity data derived from the Earth Gravitational Model EGM2008 in the Center-North Cameroon: structural and mining implications. Arabian Journal of Geosciences, 10(6), 130. https://doi.org/10.1007/s12517-017-2919-y

Feumoe, A. N. S., Ndougsa, M. T., Manguelle-Dicoum, E., \& Derek-Fairhead, J. (2012). Delineation of tectonic lineaments using aeromagnetic data for the south-east Cameroon area. Geofizika, 29, 175-192.

Gazel, J. (1955). Notice explicative sur la feuille Batouri-Ouest: carte géologique de reconnaissance à l'échelle du 1/500,000: levés effectués en 1946-1949-1952. Imprimerie Nationale.

Gazel, J., \& Gerard, G. (1954). Notice explicative sur la feuille Batouri-Est: carte géologique de reconaissance à l'échelle du 1/500.000: levés effectués de 1947 à 1951. Imprimerie Nationale.

Gibson, R. I., \& Millegan, P. S. (1998). Geology applications of gravity and magnetic: Case histories. Society of Exploration Geophysicist, 170, 162. https://doi.org/10.1190/1.9781560801832

Gunn, P. J. (1975). Linear Transformation of Gravity and Magnetic Fields. Geophysical Prospecting, 23(2), 300-312. https://doi.org/10.1111/j.1365-2478.1975.tb01530.x

Meying, A., Ndougsa, M. T., \& Manguelle-Dicoum, E. (2009). Evidence of fractures from the image of the subsurface in the Akonolinga-Ayos area (Cameroon) by combining the Classical and the Bostick approaches in the interpretation of audio-magnetotelluric data. Journal of Geology and Mining Research, 1(8), 159-171.

Miller, H. G., \& Singh, V. (1994). Potential field tilt- a new concept for location of potential field sources. Journal of applied Geophysics, 32, 213-217. https://doi.org/10.1016/0926-9851(94)90022-1

Mork, M. B. E., Mc Enroe, S. A., \& Olesen, O. (2002). Magnetic susceptibility of Mesozoic and Cenozoic sediments off Mid Norway and the role of siderite: Implications for interpretation of high resolution aeromagnetic anomalies. Marine and Petroleum Geology, 19, 1115-1126. https://doi.org/10.1016/S0264-8172(02)00115-0

Muzaffer, Ö., \& Ünal, D. (2013). Edge Detection of Magnetic Sources Using Enhanced Total Horizontal Derivative of the Tilt Angle. Bulletin of the Earth Sciences Application and Research, 34(1), 73-82.

Mvondo, H., Owona, S., Mvondo-Ondoa, J., \& Essono, J. (2007b). Tectonic evolution of the Yaoundé segment of the Neoproterozoic Central African Orogenic Belt in southern Cameroon. Canadian Journal of Earth Sciences, 44, 433-444. https://doi.org/10.1139/e06-107

Mvondo, H., Owona, S., Mvondo-Ondoa, J., Essono, J., \& Yene-Atangana, J. Q. (2007a). Comment on U-Pb dating of plutonic rocks involved in the nappe tectonic in southern Cameroon: consequence for the Pan-African orogenic evolution of the Central African fold belt. Journal of African Earth Sciences, 44, 479-493. https://doi.org/10.1016/j.jafrearsci.2007.03.002

Nabighian, M. N. (1974). Additional comments on the analytic signal of two-dimensional magnetic bodies with polygonal cross-section. Geophysics, 39, 85-92. https://doi.org/10.1190/1.1440416

Nabighian, M. N. (1984). Toward a three-dimensional automatic interpretation of potential field data via generalized Hilbert transforms: Fundamental relations. Geophysics, 49, 780-786. https://doi.org/10.1190/1.1441706

Ndougsa, M. T., Feumoe, A. N., Manguelle-Dicoum, E., \& Fairhead, J. D. (2012). Aeromagnetic Data Interpretation to Locate Buried Faults in South-East Cameroon. Geophysica, 48(1-2), 49-63.

Ndougsa, M. T., Manguelle-Dicoum, E., Tabod, C. T., \& Mbom-Abane, S. (2003). Modelisation d'anomalies gravimétriques dans la région de Mengueme-Akonolinga (Cameroun). Science, Technologie et Développement, 10, 67-74.

Ndougsa, M. T., Meying, A., Bisso, D., Layu, D. Y., Sharma, K. K., \& Manguelle-Dicoum, E. (2011). Audiomagnetotellurics (AMT) soundings based on the Bostick approach and evidence of tectonic features along the northern edge of the Congo Craton, in the Messamena/Abong-Mbang area (Cameroon). Journal of Indian 
Geophysics Union, 15(3), 145-159.

Ngako, V., Affaton, P., \& Njonfang, E. (2008). Pan-African tectonics in northwestern Cameroon: Implication for history of western Gondwana. Gondwana research, 14, 509-522. https://doi.org/10.1016/j.gr.2008.02.002

Noutchogwe, C., Tabod, C., \& Manguelle-Dicoum, E. (2006). A gravity study of the Crustal beneath the Adamawa Fault Zone, West Central Africa. Journal of Geophysics and Engineering, 3, 82-89. https://doi.org/10.1088/1742-2132/3/1/009

Owono, A. O. U. I., Ndougsa, M. T., Meying, A., Assembe, S. P., Ngoh., J. D., Ngoumou., P. C., \& Yandjimain, J. (2019). Evidence of major structural features over the Panafrican domain in the Bertoua-Mbangue area (East Cameroon) from a multiscale approach of modeling and interpretation of aeromagnetic data. International Journal of Geophysics, (12). https://doi.org/10.1155/2019/9148678

Paterson, G., \& Watson Ltd. (1976). Aeromagnetic study on certain regions of the Republic of Cameroon. Interpretation report. Canadian International Development Agency. Toronto, Canada (192 p).

Rasmussen, R., \& Pedersen, L. B. (1979). End Corrections in Potential Field Modeling: Geophysical Prospecting, 27, 49-760. https://doi.org/10.1111/j.1365-2478.1979.tb00994.x

Rasolomanana, E., Andriamirado, L. C., Randrianja, R., \& Ratefiarimino, A. (2010). Analyse et interprétation des données aéromagnétiques et spectrométriques de la région d'Andriamena. Madamines, 1, 1-14.

Reid, A. B., Allsop, J. M., Granser, H., Millett, A. J., \& Somerton, I. W. (1990). Magnetic interpretation in three dimensions using Euler Deconvolution: Geophysics, 55, 80-90. https://doi.org/10.1190/1.1442774

Rocci, G. (1965). Essai d'interpretation de mesures geochronologiques. La structure de l'Ouest africain. Sciences de la Terre, 10(3-4), 461-478.

Roest, W. R., Verhoef, J., \& Pilkington, M. (1992). Magnetic interpretation using the 3-D analytic signal. Geophysics, 57(1), 116-125. https://doi.org/10.1190/1.1443174

Salem, A., William, S., Fairhead, D., Smith, R., \& Ravat, D. (2008). Interpretation of magnetic data using tilt angle derivatives. Geophysics, 73, 1-10. https://doi.org/10.1190/1.2799992

Thompson, D. T. (1982). A new technique for making computer-assisted depth estimates from Magnetic data. Geophysics, 47, 31-37. https://doi.org/10.1190/1.1441278

Toteu, S. F., Van Schmus, W. R., Penaye, J., \& Michard, A. (2001). New U-Pb and Sm-Nd data from north-central Cameroon and its bearing on the pre-Pan African history of central Africa. Precambrian Research, 108, 45-73. https://doi.org/10.1016/S0301-9268(00)00149-2

Toteu, S. F., Penaye, J., \& Poudjom-Djomani, Y. (2004). Geodynamic evolution of the Pan-Africain Belt in Central Africa with special reference to Cameroon. Canadian Journal of Earth Sciences, 41, 73-85. https://doi.org/10.1139/e03-079

Van Schmus, W. R., Oliveira, E. P., Da Silva Filho, A. F., Toteu, S. F., Penaye, J., \& Guimães, I. P. (2008). Proterozoic links between the Borborema Province, NE Brazil, and the Central African Fold Belt. Geological Society, 294, 69-99. https://doi.org/10.1144/SP294.5

Verduzco, B., Fairhead, J. D., Green, C. M., \& Mackenzie, C. (2004). New insights into magnetic derivatives for structural mapping. The Leading Edge, SEG February, 116-119. https://doi.org/10.1190/1.1651454

Won, I. J., \& Bevis, M. (1987). Computing the Gravitational Magnetic Anomalies Due to a Polygon: Algorithm and FORTRAN Subroutines. Geophysics, 52, 232-238. https://doi.org/10.1190/1.1442298

Zanga-Amougou, A., Ndougsa-Mbarga, T., Meying, A., Layu, D. Y., Bikoro-Bi-Alou, M., \& Manguelle-Dicoum, E. (2013). 2.5 D Modeling of Crustal Structures along the Eastern Cameroon and Western Central African Republic Derived from Finite Element and Spectral Analysis Methods. Geophysica, 49.

\section{Copyrights}

Copyright for this article is retained by the author(s), with first publication rights granted to the journal.

This is an open-access article distributed under the terms and conditions of the Creative Commons Attribution license (http://creativecommons.org/licenses/by/4.0/). 